\title{
Two Channels Wireless Electrocardiograph System Using Bluetooth Communication
}

\author{
R. D. Zuhroini ${ }^{1}$, D. Titisari ${ }^{1}$, T. Hamzah ${ }^{1}$, and T. K. Kho ${ }^{2}$ \\ ${ }^{1}$ Department of Electromedical Engineering Poltekkes Kemenkes, Surabaya Jl. Pucang Jajar Timur No. 10, Surabaya, 60245, Indonesia \\ ${ }^{2}$ Faculty of Engineering and Technology, Multimedia University (Melaka Campus), Jalan Ayer Keroh Lama, 75450 Melaka, MALAYSIA.
}

Corresponding author: p27838117005@gmail.com

\begin{abstract}
Health problems with disorders of the cardiovascular system are still in high rank in the world. This is in according to data from the WHO reported that about $31 \%$ of the causes of death globally are cardiovascular diseases. The purpose of this study was to develop a 12-lead electrocardiograph with two displays and a Bluetooth HC-05 as a signal data transmitter. In this study, the electrocardiogram signal obtained from tapping was obtained by attaching electrode cables to leads I, Lead II, Lead III, aVR, aVL, and aVF. This study used IC AD620, HPF filter with frequency and LPF filter, and non-volatile inverting amplifier. Additionally, the amplifier output was feed to Arduino UNO for further display. The ECG signal was recorded and displayed on a computer monitor by using the Delphi 7 application. The research method is to measure the heart signal on the ECG Simulator and test the similarity of the signal on the ECG at $0.5 \mathrm{mV}$, $1 \mathrm{mV}$, and $2 \mathrm{mV}$ settings on each lead. The testing stage was performed. Further, the error was calculated. In this case, the highest error value is obtained for lead I, lead aVL, and aVF of 7.14\%. Additionally, the smallest error is a $3.57 \%$ error in lead III. Another finding was obtained that at the $1 \mathrm{mV}$ setting, the highest error value in lead aVL is $7.14 \%$, and the smallest error is $2.36 \%$. Moreover, at the $2 \mathrm{mV}$ setting, the highest error value is obtained in leads aVL and aVF of $5.71 \%$, and the smallest error is $2.1 \%$ for lead II. There is no significant difference between the signal generated by the module and the signal on the manufacturer's ECG.
\end{abstract}

INDEX TERMS Electrocardiograph, Heart Monitoring, HC-05, Delphi-7.

\section{INTRODUCTION}

Health problems with disorders of the cardiovascular system still rank high; according to data from the World Health Organization (WHO) it is reported that around $31 \%$ of the causes of death globally are cardiovascular disease [1][2][3]. The number of deaths caused by the symptoms of this disease cannot be seen directly, but by conducting an examination using an electrocardiograph (ECG) [4][5].

In a previous study, research conducted by Dwiky Wicaksono and Aprilia Krisnawati in 2016 has created an Electrocardiograph (ECG) 12 leads on PC. In this study, researchers used 12 leads by using multiplexer IC 4051 for data switching and using a microcontroller IC for data processing [6][7][8]. However, there are still shortcomings from this research; namely, it is still not equipped with storage for the ECG signal analysis process, and signal processing on a computer has not stabilized the signal that goes up and down the reference point [9][10]. In further research by Sugondo Hadiyoso in 2015 has created a development of 12 lead ECG devices and client-server applications for data distribution. In this study, a 12-lead ECG was designed to be controlled by a multiplexer 4051 through a microcontroller in turn[11][12][13]. Then the data is processed through $\mathrm{ADC}$ conversion and then sent serially to the server computer and can be viewed on the connected client computer. However, the ECG lead signals cannot be displayed all at once because the transfer delay is too large. A further study by Aisyah Taqiyyatun Ni'mah in 2017 has created an electrocardiograph (ECG) and PC-based photoplethysmography or PPG [14][15], [16]. In this study, the measurement of the ECG signal is only in lead II, and the graph will be displayed. On a computer using the Delphi programming language and for data transmission using the 
HC-05 module [17] [18][19] [20]. Meanwhile, to see the complete state of the heart, you need leads inferior (Lead II, Lead III, and aVF), lateral (Lead I, aVL, V5, and V6), septum (V1 and V2), anterior (V3, V4, and aVR) $[11],[7][16]$.

The purpose of this study was to develop an ECG with two display measurements on a computer via Bluetooth communication (Frontal). In building the system, several filter circuits like low pass filter, high pass filter, and notch filter will be used, and components are needed, such as the HC-05 module as a wireless concept and signal data sender in the design.

\section{MATERIALS AND METHODS}

\section{A. EXPERIMENTAL SETUP}

This study uses data retrieval per 12 ECG Signal Leads by setting the BPM signal on the Fluke ECG Simulator with settings of $30,60,120$, and 240 BPM. In each setting, a comparison will be made of each ECG lead signal at $0.5 \mathrm{mV}$, $1 \mathrm{mV}$ and $2 \mathrm{mV}$ settings between the module and the manufacturer's ECG and analysis of the working distance for the module.

\section{1) MATERIALS AND TOOL}

This study used a comparison ECG-9012A. ECG simulator as a signal generator. IC AD620 for instrumentation amplifier and TL084 as a filter and non-inverting amplifier. The microcontroller used is Arduino Uno and HC-05 for data transmission.

2) EXPERIMENT In this study, after the design was completed, the instrument was tested using an ECG simulator (phantom) with a BPM range of $30,60,120$, and 240 . Then the results were displayed to a PC, and then a comparative analysis was carried out with the recording results with the manufacturer's ECG.

\section{B. THE DIAGRAM BLOCK}

The diagram block that is shown in FIGURE 1 explains that heart signals in patients were detected using electrodes attached to the patient on the right hand (RA), left hand (LA), left leg (LL), and right foot (RL). Furthermore, in the processing block, the recorded signal enters the buffer circuit so that the detected signal is the actual signal and no signal is lost. Furthermore, with the multiplexer the tapped signal will be selected according to the logic of the microcontroller that has been inputted to the multiplexer for the selection of the tapped signal. The multiplexer output will enter the instrumentation circuit used to process the body signal. Then the signal will be filtered using a passive filter circuit that has set the frequency value according to the signal frequency value in the heart so that only heart signals are passed and block other body signals. After that the signal will enter the amplifier circuit and then enter the adder circuit which functions to increase the signal reference from negative to positive because the microcontroller can only read positive voltages so that the signal will be processed and the reference value adjusted so that it can be read by the microcontroller. The output of the adder circuit is connected to the ADC pin of the microcontroller to convert from an analog signal to digital. The modified data will be processed on the microcontroller, and the microcontroller will control the multiplexer (two-way communication between the microcontroller and PC). after processing on the microcontroller. Furthermore, the data is sent via Bluetooth communication between the HC-05 and the Delphi7 application on the PC and displays a graph of the ECG signal.

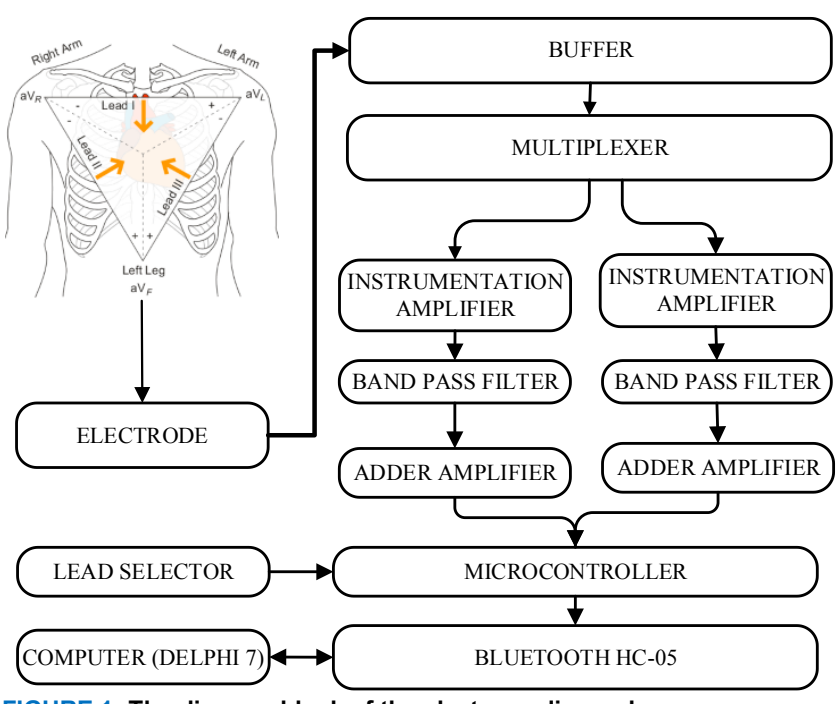

FIGURE 1. The diagram block of the electrocardiograph

\section{THE FLOWCHART}

The Arduino program was built based on the flowchart as shown in FIGURE 2. When the device is turned on in the transmitter block, there will be a lead initialization process to pick up body signals using electrodes that have been attached to the patient and a process for receiving lead selection instructions from the PC. Then the lead selection is carried out using an IC multiplexer which will then display all measurements from leads 1 and V1, leads 2 and V2, leads 3 and V3, leads aVR and V4, then leads aVL and V5 then leads aVF and lead V6. Then the measurement results will be processed in the ADC circuit which is sent via Bluetooth to the PC. In the receiver block, the user will connect to the $\mathrm{PC}$ to call the input data from the receiver. After connecting to the PC, the software is initialized. The PC will receive Bluetooth signals containing the measurement results data, then send the measurement selection results from the lead selector which will be displayed to the PC. From the previous process, the selected lead measurement data will be displayed to the PC.

\section{ANALOG CIRCUIT}

1) INSTRUMENTATION AMPLIFIER

An instrument amplifier is a closed loop amplifier. To set the desired gain, adjust it by varying the value of $\mathrm{Rg}$ (Resistor 
gain). This circuit serves to amplify the signal obtained from the Phantom ECG. The output of the instrument circuit still has a lot of noise.

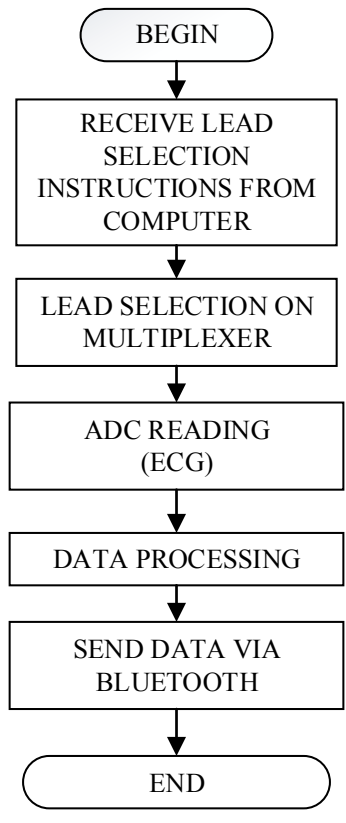

(a) (b)

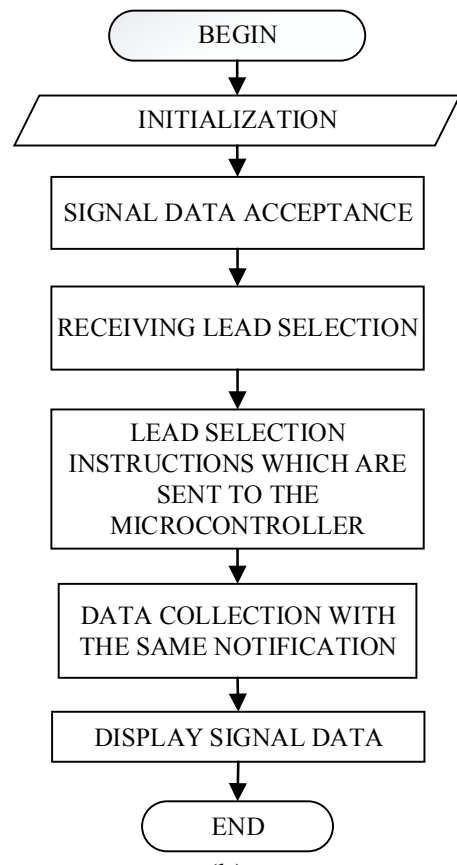

FIGURE 2. The flowchart of the Arduino program (a) transmitter and (b) receiver.

\section{2) HIGH PASS FILTER}

A high pass filter (HPF) is one type of filter that has the function of passing high frequencies and suppressing low frequencies or those less than the cut-off frequency. The ECG signal ranges from $0.05-110 \mathrm{~Hz}$; for that we need an HPF circuit that has the appropriate cut-off value. In this case the gain is $0.049 \mathrm{~Hz}$. With the following formula:

$$
f c=\frac{1}{2 \pi R C}
$$

where $\mathrm{R}$ is the resistance value and $\mathrm{C}$ is the capacitor value used.

\section{3) LOW PASS FILTER}

Low Pass filter is one type of filter that functions to pass low frequencies and suppress frequencies higher than the cut-off frequency. The ECG signal ranges from $0.05-110 \mathrm{~Hz}$, after entering the HPF circuit block, which passes frequencies above the cut-off frequency. In this study the gain is $102.6 \mathrm{~Hz}$. With the following formula:

$$
f c=\frac{1}{2 \pi \sqrt{R_{1} \times R_{2} \times C_{1} \times C_{2}}}
$$

where $\mathrm{R}$ is the resistance value and $\mathrm{C}$ is the capacitor value used.

4) NOTCH FILTER

The notch filter circuit functions as a buffer for signals that have a frequency according to the cut-off frequency and will pass signals that have a frequency outside the cut-off frequency, either less than or more than the cut-off frequency. In this study, the notch filter has a cut-off frequency of $50 \mathrm{~Hz}$. Here is the design of the Notch Filter circuit.

\section{5) NON-INVERTING AMPLIFIER}

The final amplifier circuit circuits whose function is to amplify the input, not to reverse the phase to produce a higher output.

In this study the strengthening of 27 times. With the following formula:

$$
A C L=\frac{1+R f}{R g}
$$

where ACL is instrumentation amplifier gain, $\mathrm{Rf}$ is feedback resistor and $\mathrm{Rg}$ is gain resistance.

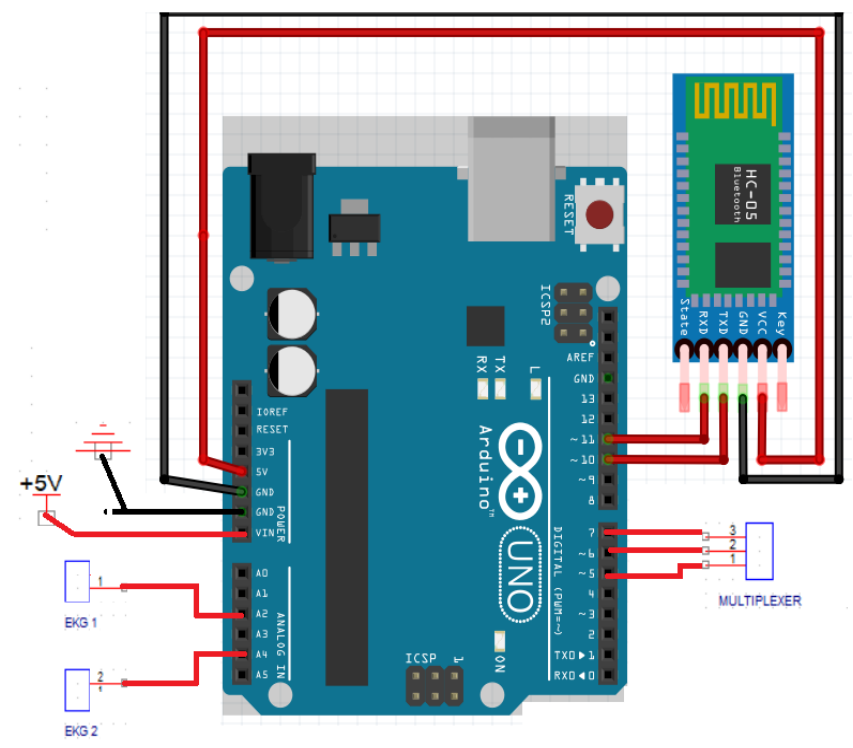

FIGURE 3. The Bluetooth connection with the others circuit

\section{6) ADDER AMPLIFIER}

The Adder Amplifier circuit serves to increase the reference to the ECG signal voltage, so that the negative voltage obtained by the ECG signal will be increased to the entire positive voltage value.

\section{7) MULTIPLEXER CIRCUIT}

The multiplexer circuit is an analog switch that is controlled or digitally controlled. The multiplexer allows to select one or more data contained in the input and for a time will be forwarded to 1 output, which is controlled on the input selection logic pin. One of the multiplexer ICs is IC $405 \mathrm{X}$ and has several types CD4051B, CD4052B, and CD4053B.

8) THE BLUETOOTH MODULE

The Bluetooth Module as shown in FIGURE 3 in this case is the HC-05. This Bluetooth module is used to transmit the ECG signal to the computer. For communication between the Arduino board and the Bluetooth module, two pins are needed, namely Tx (to transmit ECG data, and Rx to receive information between the microcontroller and the computer unit).

\section{RESULT}

In this study, the ECG was tested using a phantom ECG (Fluke, USA) and ECG and compared with the 
manufacturer's ECG (ECG-9012A). The analog section consists of four $4051 \mathrm{ICs}$ which are used as the lead selection switch. There are also 4 TL084s and some variable resistors for gain adjustment. The digital part consists of the Arduino Uno and the HC-05 Bluetooth module which is used to communicate data between the microcontroller and the PC. In this study, thic software is divided into two parts, Arduino and Delphi. To program on Arduino for setting communication speed and program initialization.

FIGURE 5 to FIGURE 7 show comparison of signal between the module with the comparison, white line for the module and black line for the manufacturer's ECG or the comparison, for setting $1 \mathrm{mV}$.



FIGURE 5. Comparison between module and ECG manufacturers at Lead I

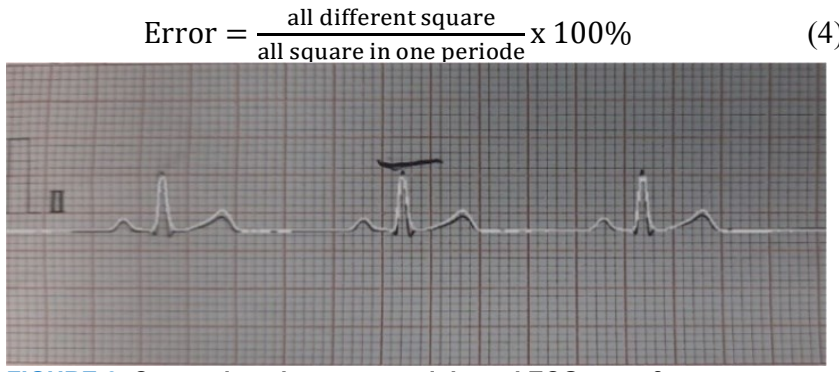

FIGURE 6. Comparison between module and ECG manufacturers at Lead II

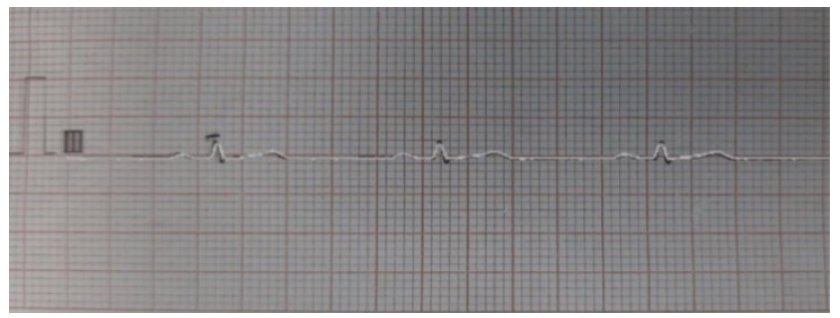

FIGURE 7. Comparison between module and ECG Manufacturer's at Lead III

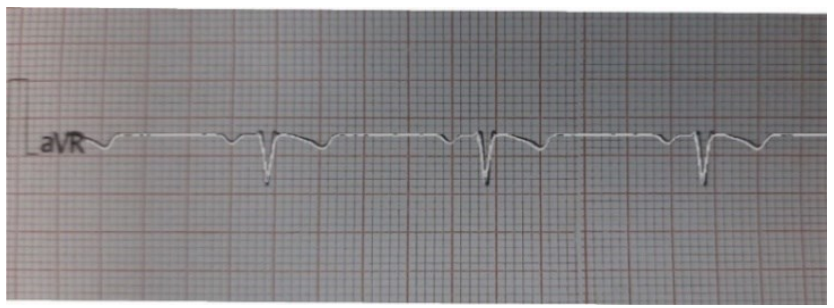

FIGURE 8. Comparison between module and ECG manufacturers at Lead aVR

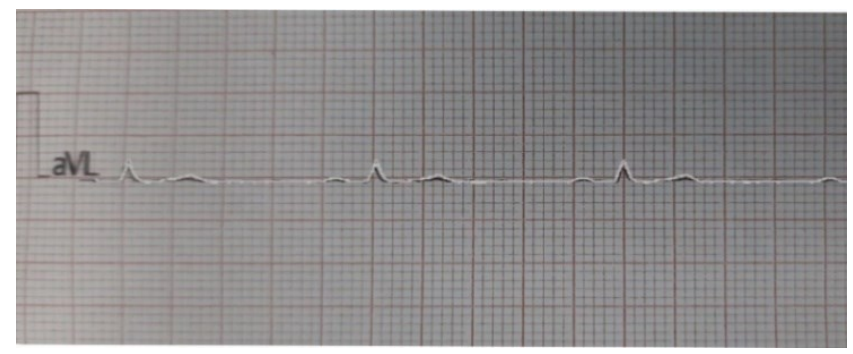

FIGURE 9. Comparison between module and ECG manufacturers at Lead aVL

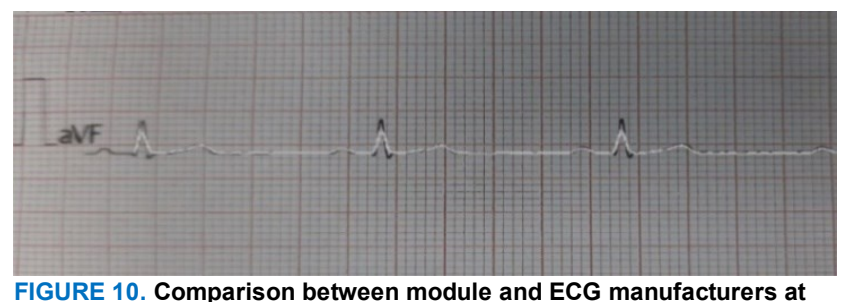
Lead aVF

TABLE 1

Comparison error between module and ECG manufacturers

\begin{tabular}{cc}
\hline \hline Lead & Error $(\%)$ \\
\hline Lead I & 2,38 \\
Lead II & 3,96 \\
Lead III & 4,76 \\
Lead aVR & 4,08 \\
Lead aVL & 7,14 \\
Lead aVF & 4,76 \\
\hline
\end{tabular}

TABLE 1 show error comparison between modules and ECG manufacturers. At the sensitivity setting of $1 \mathrm{mV}$, the average error value for all leads is $4.51 \%$; the highest error is in lead aVL of $7.14 \%$ and the lowest error is in lead I of $2.38 \%$. The testing wireless range of the ECG Module using the HC-05 Bluetooth module result was shown in TABLE 2.

\section{DISCUSSION}

The results of the signal similarity test between the module and the manufacturer's ECG at the $0.5 \mathrm{mV}$ setting for the smallest error value is $3.57 \%$ in lead III and the largest error is $7.14 \%$ in lead aVL and aVF. There is a difference in lead II, the $\mathrm{R}$ signal on the module is smaller than on the ECG. At the $1 \mathrm{mV}$ setting, the smallest error value is $2.38 \%$ in lead I and the largest error is $7.14 \%$ in lead aVL. There is a difference in the aVR where the $\mathrm{R}$ signal on the module is smaller than the ECG. At the $2 \mathrm{mV}$ setting, the smallest error value is $2.1 \%$ in lead II and the largest error is $5.71 \%$ in lead aVL. There is a difference in height in leads $\mathrm{I}, \mathrm{aVR}$, and aVF where the R signal on the module is smaller than on the ECG. Weaknesses/weaknesses of the circuit made on this ECG module is that there is a delay when transferring leads and it takes time to stabilize the signal displayed on the PC. There is no BPM value on the display on PC. 
TABLE 2

Wireless range testing

\begin{tabular}{ccc}
\hline \hline $\begin{array}{c}\text { Tx and Rx } \\
\text { Range }(\mathrm{m})\end{array}$ & Without Obstacle & With Obstacle \\
\hline 2 & Sent & Sent \\
4 & Sent & Sent \\
6 & Sent & Sent \\
8 & Sent & Sent \\
10 & Sent & Can't Sent \\
12 & Sent & Can't Sent \\
13 & Sent & Can't Sent \\
14 & Sent & Can't Sent \\
16 & Can't Sent & Can't Sent \\
\hline
\end{tabular}

In the table above, the results of testing the distance without obstruction at a distance of 16 meters, the module cannot transmit signals to a PC. For the results of distance testing with obstacles at a distance of 16 meters the module cannot transmit signals to $\mathrm{PC}$.

\section{CONCLUSION}

The purpose of this study was to develop a 12-lead electrocardiograph with 2 displays and Bluetooth $\mathrm{HC}-05$ as a signal data sender. In this study, the electrocardiogram signal obtained from tapping was obtained by attaching electrode cables to leads I, Lead II, Lead III, aVR, aVL, and aVF; This study used IC AD620, HPF filter with frequency and LPF filter and non-volatile amplifier. inverting then using Arduino UNO for further display. in the form of a signal on the Delphi 7 application. The research method is to measure the heart signal on the ECG Simulator and test the similarity of the signal on the ECG at $0.5 \mathrm{mV}, 1 \mathrm{mV}$ and $2 \mathrm{mV}$ settings on each lead. After testing the equation at the $0.5 \mathrm{mV}$ setting by calculating the error rate value, the highest error value is obtained in lead I, lead aVL and aVF of $7.14 \%$ and the smallest error is a $3.57 \%$ error in lead III. Then at the $1 \mathrm{mV}$ setting, by calculating the error rate, the highest error value in lead aVL is $7.14 \%$ and the smallest error is $2.36 \%$. At the $2 \mathrm{mV}$ setting, by calculating the error rate, the highest error value is obtained in leads aVL and aVF of $5.71 \%$ and the smallest error is the smallest error of $2.1 \%$ in lead II. There is no significant difference between the signal generated by the module and the signal on the manufacturer's ECG. For further development, it is recommended to use a signal processor on a PC to stabilize the signal that goes up and down its reference point, use components with better quality in order to produce a better signal, and add BPM values to the PC.

\section{REFERENCES}

[1] A. K. Nastiti, E. Purwanti, and A. Supardi, "Klasifikasi Kelainan Jantung Dengan Metode Transformasi Fourier Dan Jaringan Saraf Tiruan," Klasifikasi Kelainan Jantung Dengan Metod. Transform. Fourier Dan Jar. Saraf Tiruan, 2013.

[2] A. Agustiawan Surtono and G. A. Pauzi, "Sistem Instrumentasi Akuisisi Data EKG 12 Lead Berbasis Komputer," J. Teor. dan Apl. Fis., vol. 04, no. 01, pp. 67-76, 2016.

[3] A. Galli, F. Ambrosini, and F. Lombardi, "Holter monitoring and loop recorders: From research to clinical practice," Arrhythmia Electrophysiol. Rev., vol. 5, no. 2, pp. 136-143, 2016.

[4] A. K. Boyat and B. K. Joshi, "a R Eview P Aper: N Oise M Odels in D Igital I Mage P Rocessing," Signal Image Process., vol. 6, no. 2, pp. 63-75, 2015.

[5] E. Lusiana Utari, "Analisa Deteksi Gelombang QRS Untuk Menentukan Kelainan Fungsi Kerja Jantung," Teknoin Vol. 22 No. 1 Maret 2016 27-37, vol. 22, no. 1, pp. 27-37, 2016.

[6] R. Suryana, nana Aziz, "Sistem Pemonitor Detak Jantung portable menggunakan tiga sensor elektroda," J. AL-AZHAR Indones. SERI SAINS DAN Teknol. Vol. 4, No.1, Maret 2017, vol. 4, no. 1, pp. 14 17, 2017.

[7] R. J. Martis, U. R. Acharya, C. M. Lim, K. M. Mandana, A. K. Ray, and C. Chakraborty, "Application of higher order cumulant features for cardiac health diagnosis using ECG signals," Int. J. Neural Syst., vol. 23 , no. 4, 2013

[8] W. J. Iskandar, I. Roihan, and R. A. Koestoer, "Prototype low-cost portable electrocardiogram (ECG) based on Arduino-Uno with Bluetooth feature," AIP Conf. Proc., vol. 2193, no. December, 2019.

[9] S. Hadiyoso, M. Julian, A. Rizal, and S. Aulia, "Pengembangan Perangkat EKG 12 Lead dan Aplikasi Client-Server untuk Distribusi Data," ELKOMIKA J. Tek. Energi Elektr. Tek. Telekomun. Tek. Elektron., vol. 3, no. 2, p. 91, 2015.

[10] M. B. M. Kamel and L. E. George, "Remote Patient Tracking and Monitoring System," Int. J. Comput. Sci. Mob. Comput., vol. 2, no. December 2013, pp. 88-94, 2013.

[11] A. Zainuri, U. Wibawa, and E. Maulana, "Implementasi Bluetooth $\mathrm{HC}-05$ untuk Memperbarui Informasi Pada Perangkat Running Text Berbasis Android," J. EECCIS Vol. 9, No. 2, Desember 2015 , vol. 9, no. 2, pp. 164-165, 2015.

[12] K. U. Ariawan, G. S. Santyadiputra, and I. W. Sutaya, "Design of Hexapod Robot Movement Based on Arduino Mega 2560," J. Phys. Conf. Ser., vol. 1165, no. 1, 2019.

[13] R. R. Adiputra, S. Hadiyoso, and Y. Sun Hariyani, "Internet of things: Low cost and wearable $\mathrm{SpO} 2$ device for health monitoring," Int. J. Electr. Comput. Eng., vol. 8, no. 2, pp. 939-945, 2018.

[14] A. T. Ni'mah, "Elektrokardiograf dan Photoplethysmograf berbasis PC," Semin. Tugas Akhir, pp. 1-8, 2017.

[15] H. D. Ray, "Anatomi Jantung Manusia," Sist. Anat. Jantung Mns., vol. 2, no. 4, pp. 12-14, 2018.

[16] F. Buendía-Fuentes et al., "High-Bandpass Filters in Electrocardiography: Source of Error in the Interpretation of the ST Segment," ISRN Cardiol., vol. 2012, pp. 1-10, 2012.

[17] P. . John E. Hall, Textbook of Medical Physiology, 12th ed., vol. 4, no. 1. United States of America: Saunders, Elsevier Inc, 2011.

[18] Jay, Buku Ajar Pelatihan EKG Untuk Perawat Cardio Vasculer Care Unit. Malang, 2010.

[19] Maxim Integrated, "MAX30100 Pulse Oximeter and Heart-Rate Sensor IC for Wearable Health," Lect. Notes Energy, vol. 38, pp. 1137, 2014.

[20] T. K. Kho, R. Besar, Y. S. Tan, K. H. Tee, and K. C. Ong, "Bluetooth-enabled ECG Monitoring System," in TENCON 2005 2005 IEEE Region 10 Conference, 2005, pp. 1-5.

[21] S. Pendukung, K. Pemilihan, K. Teladan, P. Sentra, D. Metode, and P. Profil, "Jurnal teknik informatika," vol. 5, no. 2, 2017. 


\section{APPENDIX}

Program 1. For Data Processing



In the above program is a signal processing program that is connected to the Arduino from the output of the ECG filter circuit. The result of the signal read by pin 4 and pin 2 of Arduino is processed before being sent to Delphi via Bluetooth HC-05

\section{Program 2. Display}

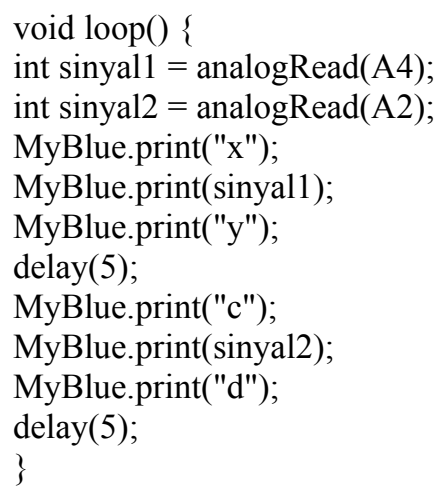

The above program is a program for the signal that will be read as analog data and then sent to the interface display by Bluetooth $\mathrm{HC}-05$ by analog pins A 4 and A 2 and will later be adjusted to the address on the display application on the PC (Delphi).

Program 3. For Lead Selection



Journal homepage: jeeemi.org

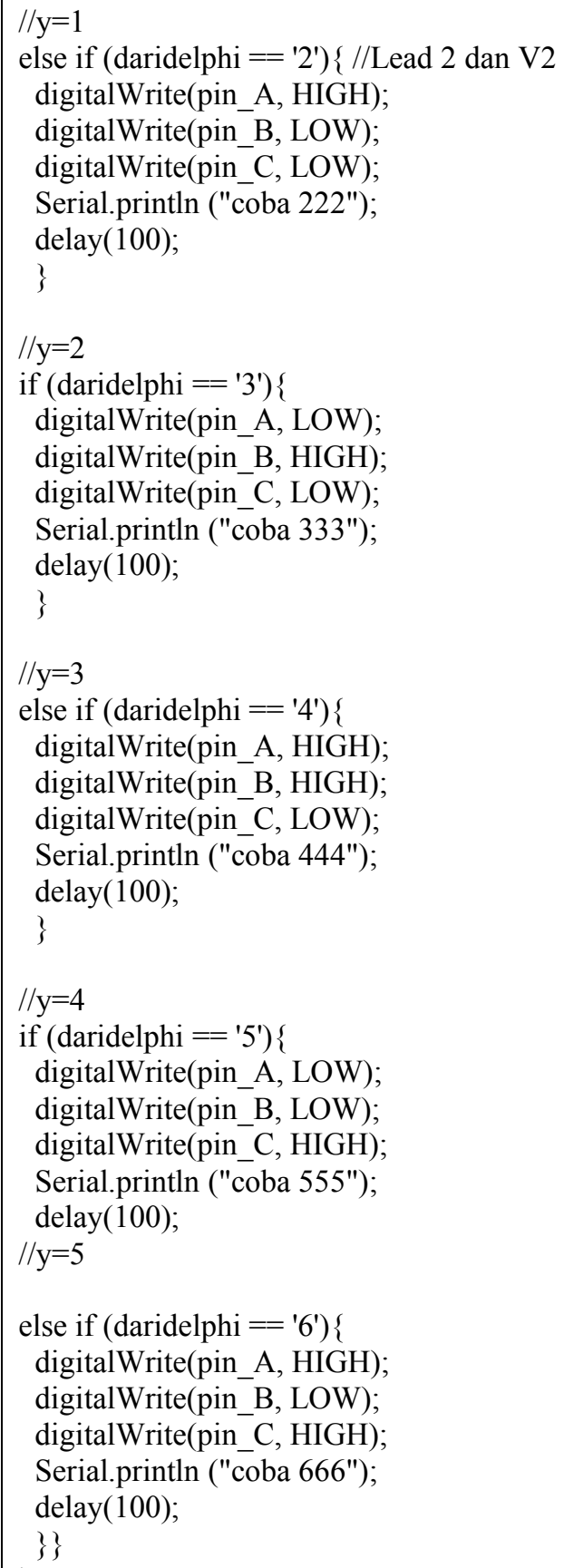

In making the module display using this delphi application as shown in FIGURE 4, programming includes the graph for ECG signal, both frontal and transversal reading display program, and the setting for lead selection, and ON/OFF button. 


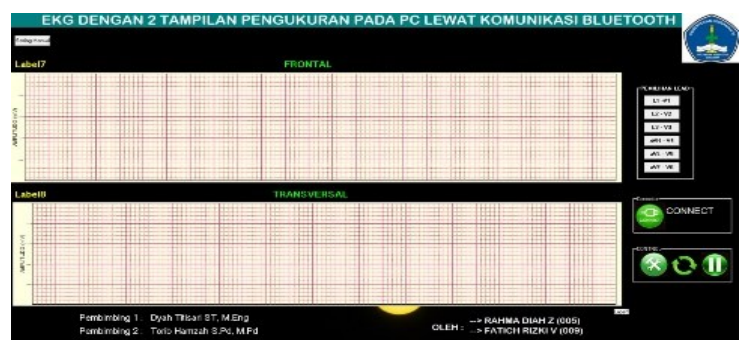

FIGURE 4. The Display of ECG in Delphi 7 application

Program 4. To connect the ECG

//----------choose port----------------------------

Procedure

TForm1.Button7Click(Sender: TObject);

begin

Comport1.Port:=InputBox('Setting','Masukkan

Port',Comport1.Port);

procedure TForm1.ComDataPacket2Packet(Sender: TObject; const Str: String);

//-----------CONNECT-

procedure

TForm1.Image4Click(Sender: TObject);

Begin

The above program is a program in Delphi which is used to receive data sent $\backslash$ choose the port to be used and then connected with the "CONNECT" button. Will be connected when the connect button changes to "CONNECTED".

Program 5. To display data on Delphi 7

//----------------data processing ecg------------
procedure TForm1.ComDataPacket7Packet(Sender:
TObject; const Str: String);
Var
E,dataadc: Integer;
tegangan: Real;
begin
Val(Str,dataadc,E);
if E $<0$ then Exit;
tegangan:=dataadc*0.0038875855327468230694037145
$65 ;$
Chart1.Series[0].AddXY(x,tegangan);
x:=x+0.17;
if chart1.Series[0].MaxXValue $>$
Chart1.BottomAxis.Maximum then begin
Chart1.Series[0].Clear;
x:=0;
end;
//------------------------2---------------------------------
procedure TForm1.ComDataPacket1Packet(Sender:
TObject; const Str: String);
Var
E1,dataadc1: Integer;
tegangan1, teganganbaru: Real;
begin
Val(Str,dataadc1,E1);

if E1 $<>0$ then Exit;

tegangan $1:=$ dataadc $1 * 0.00388758553274682306940371$

4565;

end;

end;

Chart2.Series[0].AddXY(x1,tegangan 1$)$;

$\mathrm{x} 1:=\mathrm{x} 1+0.17$

if chart2.Series[0].MaxXValue $>$

Chart2.BottomAxis.Maximum then begin

Chart2.Series[0].Clear;

$\mathrm{x} 1:=0$; 